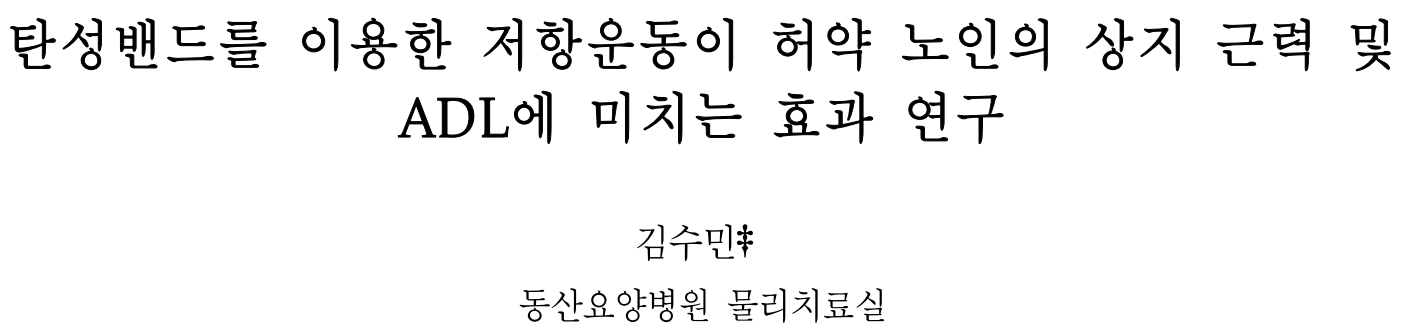

\title{
Effect of Elastic Band Based Resistance Exercise on Upper Limbs Strength and ADL of Frail Elders
}

\author{
Soo-Min Kim $\ddagger$ \\ Department of Physical Therapy, Dongsan Silver Hospital
}

\begin{abstract}
$<$ Abstract $>$
The purposes of this study were to effect the upper extremities strength and ADL with upper extremities in frail elders.

This study comparison upper extremities strength to pre-exercise and post-exercise and ADL with upper extremities. 30 elders who was in C silver hospital in Busan after resistance exercise during 12 weeks using elastic band, It was confirmed that improvement upper extremities strength and ADL with upper extremities after resistance exercise.

As a result of study about effect of elastic band based resistance exercise on ADL of frail elders, it seems to have good effect on over all items(eating, dressing, bathing, make-up, go to a rest room). Therefore, it is necessary to find method about rehabilitation exercise for frail or partial disability elders.
\end{abstract}

Key Words : Resistance Exercise, Elastic Band, Upper Limbs Strength, Activities of Daily Living 


\section{I. 서론}

노인에 있어서 운동은 심혈관 기능 개선, 골 손 실 감소, 근육과 근력 증가, 유연성 증가, 콜레스테 롤 수치 개선의 효과와 균형 및 근골격계 교정, 낙 상의 감소, 순환기능의 호전을 주고[1] 신체적 허 약을 보완하며, 건강 체력요소인 근력, 근지구력, 심폐지구력, 유연성 등을 발달시켜 암이나 만성퇴 행성질환과 기타 질병발생력을 억제하도록 신체의 면역기능을 향상시킨다[2]. 또한 궁극적으로 만성 퇴행성질환을 조절 - 관리하는 역할을 함으로서 병 이 악화되거나 기타 합병증의 유발율을 낮추는 치 료기능을 갖는다.

우리나라의 노인인구는 급속히 고령화되고 있으 며, 80세 이상의 후기고령자의 증가가 뚜렷이 나타 나고 있는데, 이는 만성질환이나 고령 등으로 타인 의 도움을 받아야 하는 활동 장애 노인이 늘어나고 있음을 의미한다. 이에 문옥륜[3]은 일상활동수행능 력(Activities of Daily Living, ADL)의 저하로 장애 노인 인구가 증가할 것이라고 하였고, 선우덕 등[4] 은 $\mathrm{ADL}$ 장애노인의 운동 빈도가 일반노인에 비해 현격하게 감소하는 양상을 보이고 있다고 하였다.

재활운동에 대한 참여가 높을수록 노인의 건강 상태와 $\mathrm{ADL}$ 능력이 향상된다고 이미 알려진 바 있 고[5][6], 노인에게 체력적인 부담을 줄이면서 저항 력을 통해 근력기능을 극대화하는 운동방법들이 제기될 수 있는데, 탄성밴드운동은 이러한 점에서 부합된다고 할 수 있다[7].

탄성밴드운동에 대한 선행 연구에서, 다양한 계 층을 대상으로 긍정적 효과가 있었음을 보고하였 으나[8[9][10], 대부분이 건강한 사람들을 대상으로 하였으며, 노인환자를 대상으로 한 연구[11][12]가 있었으나, 상지의 $\mathrm{ADL}$ 기능에 대한 조사는 일부 에 지나지 않았다. 이에 본 연구는 탄성밴드를 이 용한 저항운동이 허약노인의 상지 근력 및 $\mathrm{ADL}$ 에 미치는 효과에 대해 알아보고자하였다.

\section{ㅍ. 연구방법}

\section{1. 연구 대상 및 기간}

부산광역시 소재 $\mathrm{C}$ 요양병원에 입원 중에 있으 며, 의사소통 및 지각에 문제가 없고 상지의 근력 이 허약한 상태이나 탄성밴드를 이용할 수 있는 정도인 ' $\mathrm{F}$ '등급 이상의 기능[13]을 가지고 있는 노 인 30 명을 연구대상으로 하였다.

연구기간은 2011년 7월 1일부터 10월 31일까지 12 주간 대상자에게 저항력이 낮은 탄력 밴드 $(0.5 / \mathrm{kg})$ 를 이용하여 주 3 회(회/15분)로 저항운동 을 실시한 후 운동전과 비교하여 상지 근력 및 $\mathrm{ADL}$ 의 변화를 조사하였다.

\section{2. 자료 수집 및 분석}

상지근력변화에 대한 자료는 국민건강증진을 위 한 운동능력평가 기준표[14]와, Rikli \& Jones[15]가 개발한 노인 체력 검사(Fitness Seniors Test)표를 참고로 하여 4 개 항목으로 측정표를 재구성하였다. 체력 측정에 사용된 기구는 <그림 1 >과 같다.

남자의 측정항목 중 '엎드려 상체 들기'는 배를 바닥에 닿은 상태로 측정하였고, 여자는 이에 상응 하는 '짐볼 던지기'를 시행하였다. 이는 Elizabeth 등[16]의 허약한 노인들에 대한 상지의 저항력을 평가하기 위한 방법을 응용한 것이다<표 1>.

$\mathrm{ADL}$ 의 평가표<표 2>는 상지기능 5 개 항목의 평 가 척도로서 대상자가 스스로 기입하도록 한 후 채집 하였으며, 분석도구는 SPSS 19.0 for Windows를 사 용하여 운동 전·후의 상지 근력 변화는 대응표본 $\mathrm{t}$ 검정(paired t-test)을 실시하였고, 상지 근력 간의 관 련성을 피어슨 상관분석으로 검정하였다. 또한 $\mathrm{ADL}$ 의 변화는 빈도분석을 산출하였으며, 유의수준 $\alpha$ 는 0.05 로 하였다. 연구방법에 대한 절차는 <그림 2>과 같다. 

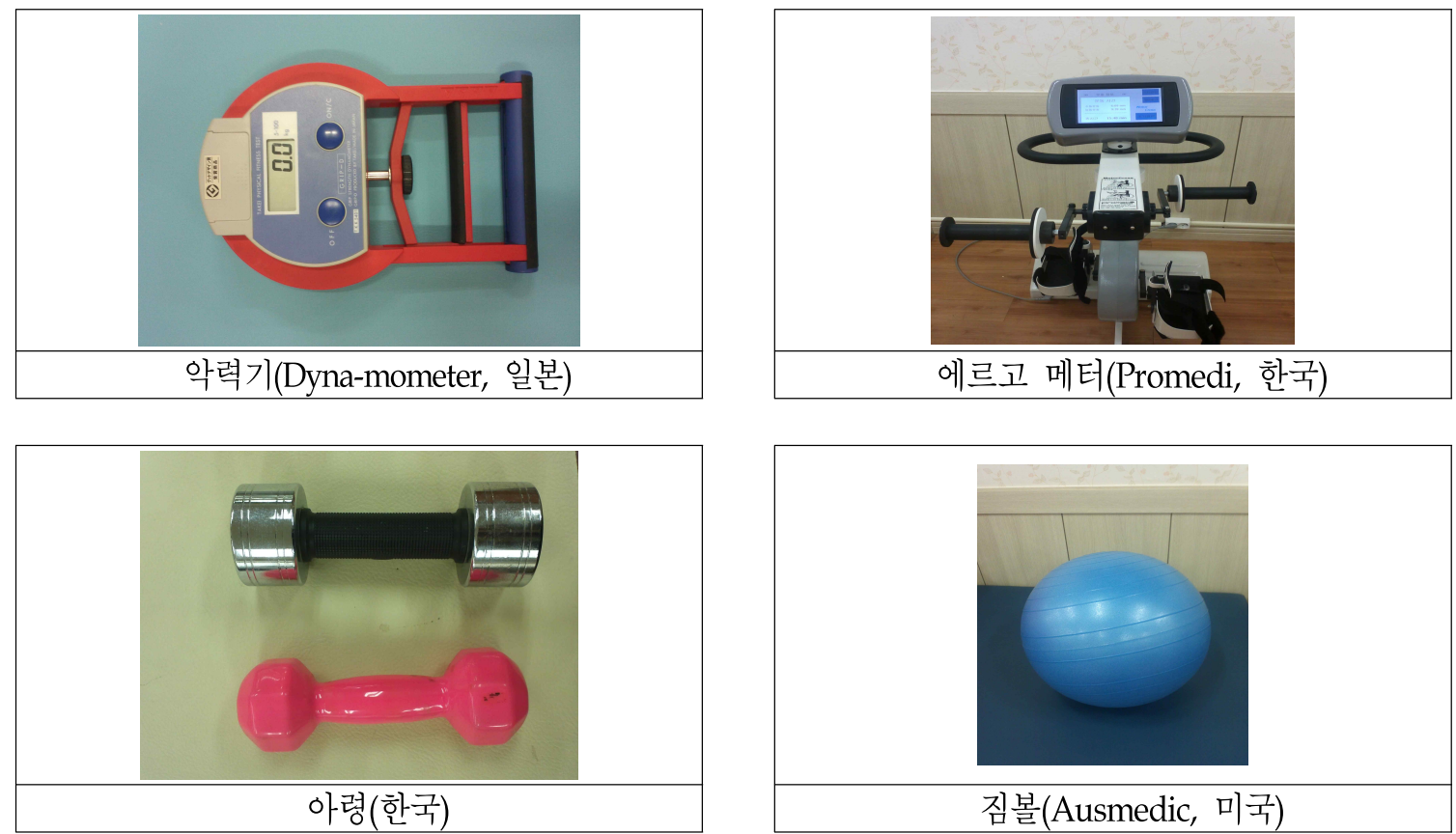

<그림 1> 근력 측정 기구

<표 1> 상지 근력 측정표

\begin{tabular}{|c|c|c|c|c|}
\hline \multirow{2}{*}{ 순번 } & \multirow{2}{*}{ 테스트 항목 } & \multirow{2}{*}{ 목적 } & \multirow{2}{*}{ 내용 } & \multirow{2}{*}{$\begin{array}{c}\text { 측정 } \\
\text { 우동 저 우도 흐 }\end{array}$} \\
\hline & & & & \\
\hline 1 & 악력 & 손가락 근력 평가 & 악력기를 이용하여 좌,우 각각 2회 측정 ( $\mathrm{kg}$-평균) & \\
\hline 2 & 팔 구부리고 펴기 & 전완 및 상완 근력 평가 & $\begin{array}{l}\text { 여자는 } 2 \mathrm{~kg} \text {, 남자는 } 3.5 \mathrm{~kg} \text { 의 아령을 들고 } \\
\text { 팔꿈치를 완전히 구부렸다 펴기(30초/횟수) }\end{array}$ & \\
\hline \multirow{2}{*}{3} & 엎드려 상체 들기(남) & 사지 그려 펴기 & 복부를 바닥에 붙인 상태에서 상체를 들기(30초/횟수) & \\
\hline & 짐볼 던지기(여) & & 짐볼 $(1 \mathrm{~kg})$ 을 두 손으로 잡고 최대한 멀리 던지기 $(3$ 회 $/ \mathrm{m})$ & \\
\hline 4 & 에르고메터 측정 & 상지 근력 평가 & $\begin{array}{l}\text { 상지용 에르고메터로 1(최저)-12(최고) } \\
\text { level 정도 측정 }\end{array}$ & \\
\hline
\end{tabular}

<표 2> ADL 평가표

\begin{tabular}{ll}
\hline 항목 & 평가 척도 \\
\hline \hline 식사하기 & 더 나빠졌다 \\
몸 단장하기 & 별 차이 없다 \\
목욕하기 & 약간 도움 \\
옷 벗고 입기 & 매우 도움 \\
화장실 사용하기 & \\
\hline
\end{tabular}




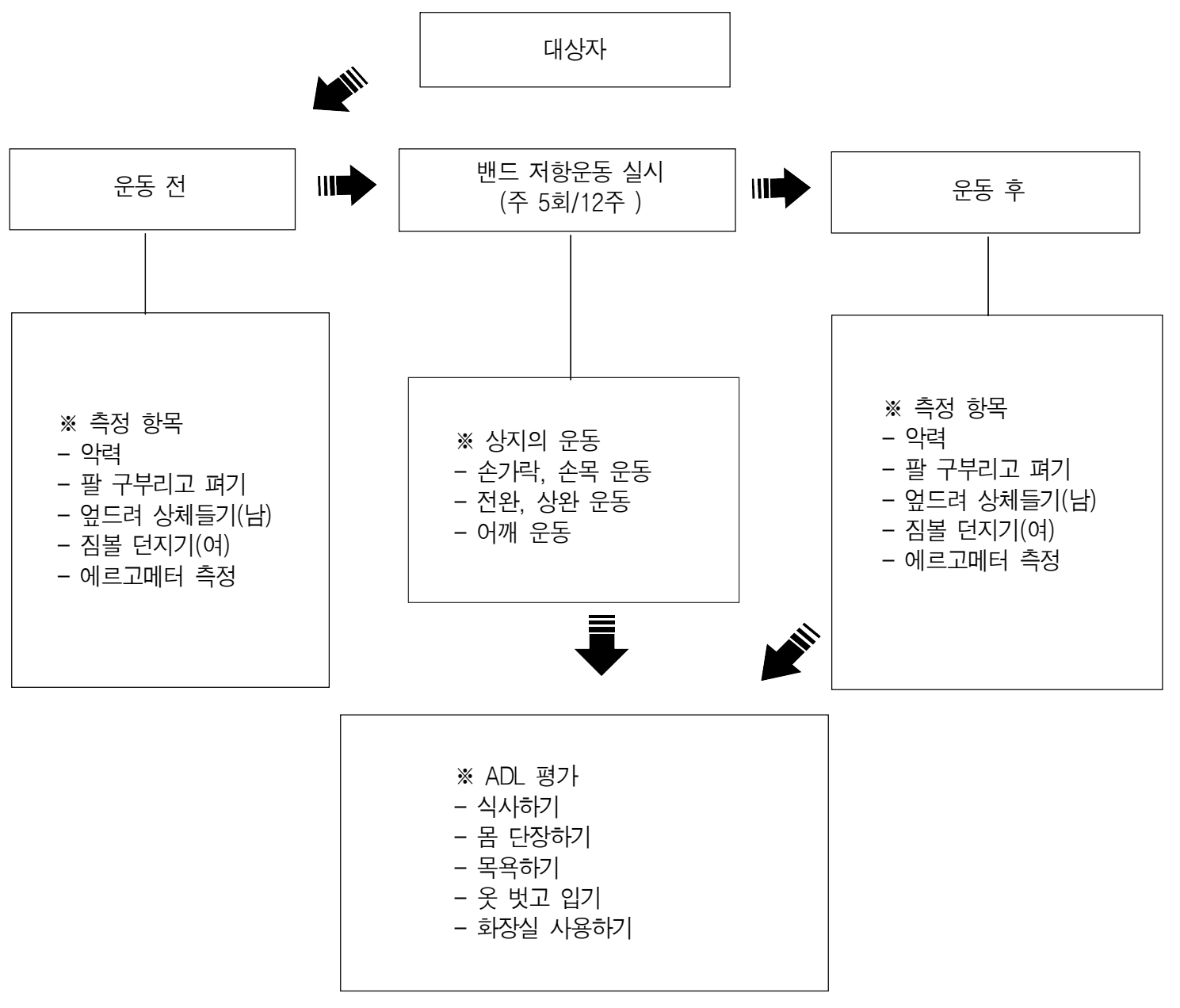

<그림 2> 연구 절차

III. 연구 결과

1. 일반적 특성

전체 대상자의 성별은 남성이 12 명 $(40.0 \%)$, 여성 이 18 명 $(60.0 \%)$ 이었고, 평균 연령은 $79.00 \pm 6.46$ 세 이었으며, 남성 평균연령이 $80.00 \pm 5.72$ 로 여성에 비해 약간 높았다. <표 3>.
<표 3> 일반적인 특성

\begin{tabular}{clc}
\hline & 대상자 & 빈도(\%), 평균 \pm 표준편차 \\
\hline \hline 성별 & 남 & $12(40.0)$ \\
& 여 & $18(60.0)$ \\
\hline 나이 & 남 & $80.00 \pm 5.72$ \\
& 여 & $78.22 \pm 6.97$ \\
& 평균 & $79.00 \pm 6.46$ \\
\hline
\end{tabular}


2. 운동 전·후 전체 대상자의 상지근력 비교

밴드 저항운동 전과 후의 상지근력의 분석 결과 에서, '악력'은 운동 전, $20.55 \pm 8.60$ 에서 운동 후, $21.29 \pm 8.95$ 로 증가한 것으로 나타나 유의한 차이를 보였다. 또한 '팔 구부리고 펴기'에서도 운동 전, $5.60 \pm 2.53$ 에서 운동 후, $6.57 \pm 2.97$ 로 증가하여 유의 한 차이를 보였다. '에르고메터 측정'에서는 운동 전, $4.47 \pm 2.03$ 에서 운동 후, $5.37 \pm 2.65$ 이었고, 운동 전·후의 '엎드려 상체 들기(남자)'는 각각 $2.80 \pm 3.95,3.07 \pm 4.40$ 이었으며, 운동 전 · 후의 '짐볼 던지기(여자)'는 각각 $1.25 \pm 1.06,1.35 \pm 1.15$ 로 이들 항목 모두에서 유의한 차이를 보였다<표 4>.

3. 운동 전·후 남성 노인의 상지근력 비교

남성 노인의 상지근력 분석 결과, '악력'은 운동
전, 29.59( \pm 6.16$)$ 에서 운동 후, 30.56( \pm 6.55$)$ 로 증가 한 것으로 나타나 유의한 차이를 보였다. 또한 '팔 구부리고 펴기'에서도 운동 전, $7.42( \pm 2.39)$ 에서 운 동 후, 6.57( \pm 3.03$)$ 로 증가하여 유의한 차이를 보였 다. '엎드려 상체 들기'는 $7.00( \pm 3.06)$ 에서 7.67( \pm 3.55$)$ 이었으며, ‘에르고메터 측정'에서는 $6.00( \pm 1.35)$ 에서 $7.33( \pm 2.15)$ 로 증가하여 이들 항목 모두에서 유의한 차이를 보였다<표 5>.

4. 운동 전, 후 여성 노인의 상지근력 비교 여성 노인의 상지근력 분석 결과, '악력'은 운동 전, $14.53( \pm 2.37)$ 에서 운동 후, $15.12( \pm 2.81)$ 로 증가하 였으며, '팔 구부리고 펴기'에서도 운동 전, $4.39( \pm 1.82)$ 에서 운동 후, $5.22( \pm 2.07)$ 로 증가하여 유 의한 차이를 보였다.

\begin{tabular}{|c|c|c|c|c|}
\hline \multirow{2}{*}{ 테스트 항목 } & \multicolumn{2}{|c|}{ 평균士표준편차 } & \multirow{2}{*}{$\mathrm{t}$} & \multirow{2}{*}{$p$-value } \\
\hline & 운동 전 & 운동 후 & & \\
\hline 악력 & $20.55 \pm 8.60$ & $21.29 \pm 8.95$ & -4.869 & .000 \\
\hline 팔 구부리고 펴기 & $5.60 \pm 2.53$ & $6.57 \pm 2.97$ & -6.922 & .000 \\
\hline 에르고메터 측정 & $4.47 \pm 2.03$ & $5.37 \pm 2.65$ & -4.791 & .000 \\
\hline 엎드려 상체 들기(남) & $2.80 \pm 3.95$ & $3.07 \pm 4.40$ & -2.804 & .009 \\
\hline 짐볼 던지기(여) & $1.25 \pm 1.06$ & $1.35 \pm 1.15$ & -2.739 & .010 \\
\hline
\end{tabular}

<표 5> 남성 노인의 상지 근력 변화

단위: 평균 \pm 표준편차

\begin{tabular}{|c|c|c|c|c|c|c|c|c|}
\hline \multirow{3}{*}{$\begin{array}{l}\text { 측정 항목 } \\
\text { 악력 }\end{array}$} & \multirow{2}{*}{\multicolumn{3}{|c|}{$\begin{array}{c}\text { 운동 전 } \\
\text { 평균士표준편차 }\end{array}$}} & \multirow{2}{*}{\multicolumn{3}{|c|}{$\begin{array}{c}\text { 운동 후 } \\
\text { 평균士표준편차 }\end{array}$}} & \multirow{3}{*}{$\frac{t}{-3.397}$} & \multirow{3}{*}{$\begin{array}{c}\begin{array}{c}p^{-} \\
\text {value }\end{array} \\
.006\end{array}$} \\
\hline & & & & & & & & \\
\hline & 29.59 & \pm & 6.16 & 30.56 & \pm & 6.55 & & \\
\hline 팔 구부리고 펴기 & 7.42 & \pm & 2.39 & 8.58 & \pm & 3.03 & -4.311 & .001 \\
\hline 엎드려 상체 들기 & 7.00 & \pm & 3.06 & 7.67 & \pm & 3.55 & -3.546 & .005 \\
\hline 에르고메터 측정 & 6.00 & \pm & 1.35 & 7.33 & \pm & 2.15 & -3.546 & .005 \\
\hline
\end{tabular}


'짐볼 던지기'에서는 $1.98( \pm 0.58)$ 에서 2.14 $( \pm 0.63)$ 이었으며, '에르고메터 측정'에서는 $3.44( \pm 1.76)$ 에서 $4.06( \pm 2.01)$ 으로 증가하여 이들 항목 모두에서 유의 한 차이를 보였다<표 6>.

\section{5. 운동 후 상지 근력 간의 상관분석}

'악력'과 '짐볼 던지기'는 음적(-) 상관관계를 보 였으며 상관계수의 유의성은 없었지만 '악력'과 '팔 구부리고 펴기', '악력'과 '에르고메터', '악력'과 '엎 드려 상체 들기’는 양적(+) 상관관계를 보였으며, 상관계수의 유의성이 있었다.

'팔 구부리고 펴기'와 '짐볼 던지기'는 음적 상 관관계를 보였으며 상관계수는 유의성이 없었지만 '팔 구부리고 펴기'와 '에르고메터', '팔 구부리고 펴기'와 '엎드려 상체 들기'는 양적 상관관계를 보 였으며 상관계수는 유의성이 있었다.

'에르고메터'는 '짐볼 던지기'와 양적 상관관계 를 보였으며 상관계수의 유의성은 없었지만 '에르 고메터'와 '엎드려 상체 들기'는 양적 상관관계를 보였으며 상관계수의 유의성이 있었다.
‘엎드려 상체 들기'와 '짐볼 던지기'는 성별에 따라 구분해서 실시한 테스트 항목이므로 상관성 검정에 해당사항이 없으므로 분석에서 제외하였다.

유의한 상관관계를 보인 변수들은 '악력'과 '팔 구부리고 펴기', '악력'과 '에르고메터', '악력'과 '엎 드려 상체 들기','팔 구부리고 펴기'와 '에르고메터', '팔 구부리고 펴기'와 '엎드려 상체 들기', '에르고 메터'와 '엎드려 상체 들기' 항목이었으며 모두 양 적 상관관계를 보였다.

즉, '악력'이 증가할수록 '팔 구부리고 펴기', '에 르고메터', '엎드려 상체 들기'가 향상되고, '팔 구부 리고 펴기'가 증가할수록 '에르고메터', '엎드려 상체 들기'가 향상되며, '에르고메터'가 증가할수록 '엎드 려 상체 들기'도 향상되는 것으로 나타났다<표 7>.

6. 운동 후 전체 대상자의 $\mathrm{ADL}$ 기능 변화

식사하기의 항목에서는 '조금 도움'이 12 명 $(40.0 \%)$ 으로 가장 높았고, '매우 도움'과 별 차이 없다가 각각 8 명 $(26.7 \%)$ 이었다.

<표 6> 여성 노인의 상지근력 변화

\begin{tabular}{|c|c|c|c|c|c|c|c|c|}
\hline \multirow{2}{*}{$\begin{array}{l}\text { 측정 항목 } \\
\text { 악력 }\end{array}$} & \multicolumn{3}{|c|}{$\begin{array}{l}\text { 운동 전 } \\
\text { 평균士표준편차 }\end{array}$} & \multicolumn{3}{|c|}{$\begin{array}{l}\text { 운동 후 } \\
\text { 평균士표준편차 }\end{array}$} & \multirow{2}{*}{$\frac{t}{-3.559}$} & \multirow{2}{*}{$\begin{array}{c}\begin{array}{c}p^{-} \\
\text {value }\end{array} \\
.002\end{array}$} \\
\hline & 14.53 & \pm & 2.37 & 15.12 & \pm & 2.81 & & \\
\hline 팔 구부리고 펴기 & 4.39 & \pm & 1.82 & 5.22 & \pm & 2.07 & -5.718 & .000 \\
\hline 짐볼 던지기 & 1.98 & \pm & 0.58 & 2.14 & \pm & 0.63 & -2.843 & .001 \\
\hline 에르고메터 측정 & 3.44 & \pm & 1.76 & 4.06 & \pm & 2.01 & -3.716 & .002 \\
\hline
\end{tabular}

<표 7> 운동 후 상지 근력 간의 상관분석

\begin{tabular}{lcccc}
\hline & 짐볼 던지기 & 엎드려 상체 들기 & 에르고메터 & 팔 굽히고 펴기 \\
\hline \hline 엎드려 상체 들기 & -.265 & & & \\
에르고메터 & -.117 & $.631 * *$ & & \\
팔 구부리고 펴기 & -.090 & $.369 *$ & $.609 * \star$ & \\
악력 & -.120 & $.428 *$ & $.621 * *$ & $.376 *$ \\
\hline
\end{tabular}

$\star p<.05, * * p<.01$ 
몸 단장(세수, 화장 등)하기의 항목에서는 '조금 도움'이 14 명 $(46.7 \%)$, '매우 도움'이 7명 $(23.3 \%)$ 으로 전반적으로 도움이 되었다는 의견이 과반수 이상 이었다.

목욕하기의 항목에서는 '매우 도움'이 12 명 $(40.0 \%)$, '조금 도움'이 9명(30.0\%)으로 대부분 도움 이 되었다는 긍정적인 답변을 하였다.

옷 벗고 입기의 항목에서는 '조금 도움'이 10 명 (33.3\%)으로 가장 많았고, '매우 도움'도 8명(26.7\%) 이었지만 '별 차이 없음'도 9명 $(30.0 \%)$ 있었다.

화장실 사용하기의 항목에서는 '조금 도움'이 13 명(43.3\%), '매우 도움'이 2명(6.7\%)으로 절반 이상 이 호전되었다는 결과를 나타내었지만 '별 차이 없 음'의 답변도 11 명 $(36.7 \%)$ 있었다<그림 3>.

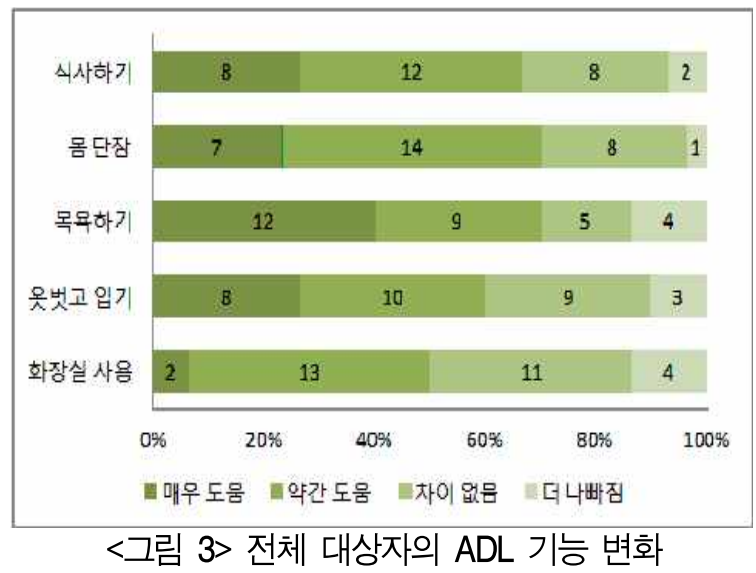

7. 운동 후 남성 노인의 $\mathrm{ADL}$ 기능 변화

식사하기의 항목에서는 '조금 도움'이 5 명 $(41.7 \%)$ 으로 가장 높았고, 그 다음으로 '별 차이 없 다가 4 명(33.3\%)으로 높았다. 몸 단장(세수, 화장 등)하기의 도움에 관한 항목에서는 '조금 도움'이 6 명(50.5\%)으로 가장 높았고, 그 다음으로 '별 차이 없다'가 5명 $(41.7 \%)$ 으로 높았다.

목욕하기의 항목에서는 '조금 도움'이 5 명 $(41.7 \%)$, '매우 도움'이 3명(25.0\%)으로 과반수 이상
이 호전되었음을 보였다.

옷 입고 벗기의 항목에서는 '별 차이 없음'이 4 명 $(33.3 \%)$, '조금 도움'과 '더 나빠짐'이 각각 3명 (25.0\%)으로 나타나 호전되지 않은 경우가 더 많았 다.

화장실 사용하기의 항목에서는 '조금 도움'이 5 명 $(41.7 \%)$ 이 가장 많았고, 그 다음으로 '별 차이 없 다'가 4명(33.3\%)으로 나타났다<그림 4>.

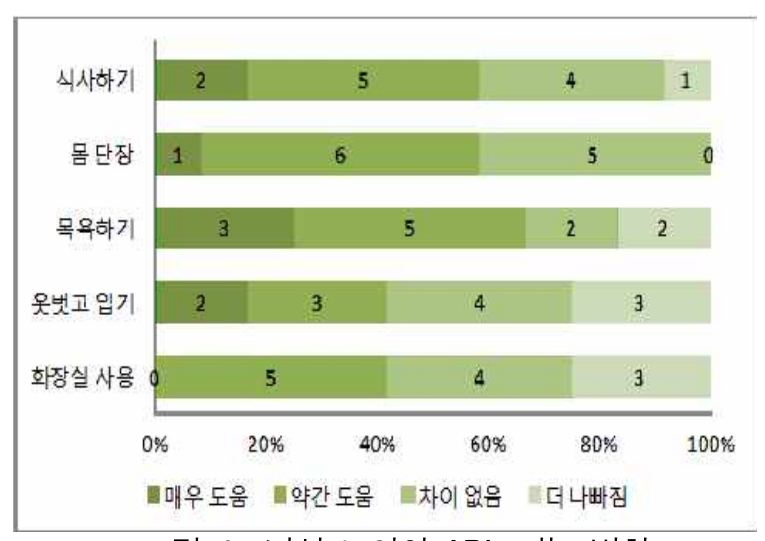

<그림 4> 남성 노인의 $\mathrm{ADL}$ 기능 변화

8. 운동 후 여성 노인의 $\mathrm{ADL}$ 기능 변화

식사하기의 항목에서는 '조금 도움'이 7명 $(38.9 \%)$ 으로 가장 높았고, 다음으로 '매우 도움'이 6명 $(33.3 \%)$ 으로 응답하여 과반수이상이 호전되었음 을 나타내었다.

몸단장(세수, 화장 등)하기의 항목에서는 '조금 도움'이 8명(44.4\%), '매우 도움'이 6명(33.3\%)으로 대부분 호전되었음을 나타내었다.

목욕하기의 항목에서는 '매우 도움'이 9명 $(50.0 \%)$, '조금 도움'이 4 명 $(22.2 \%)$ 으로 과반수이상 이 호전되었음을 나타내었다.

옷 벗고 입기의 항목에서는 '조금 도움'이 7명 $(38.9 \%)$ 으로 가장 많았고, '매우 도움'도 6명 $(33.3 \%)$ 으로 나타나 과반수이상이 호전되었지만 '별 차이 없음도 5 명 $(27.8 \%)$ 있었다. 
화장실 사용하기의 항목에서는 '조금 도움'이 8 명(44.4\%), ‘별 차이 없음'이 7명(38.9\%), '매우 도 움'이 2명 $(11.1 \%)$, '더 나빠졌다'가 1 명 $(5.6 \%)$ 으로 큰 차이를 보이지 않았다<그림 5>.

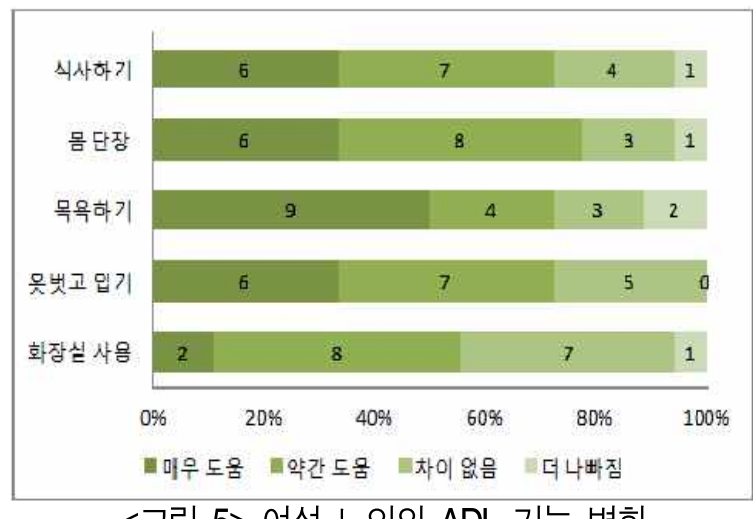

<그림 5> 여성 노인의 $\mathrm{ADL}$ 기능 변화

\section{IV. 고찰}

최근 고령자들에게도 근력 운동을 권장하고 있 는데 이는 고령에 따른 근육 위축 및 상실의 노화 현상을 근육 강화 운동으로 둔화 시킬 수 있다는 인체 생리학적 근거에 기인한다.

탄성밴드 운동은 개인의 체력에 맞는 강도 조절 이 가능하고 근력에 따라 밴드의 강도를 서서히 높여가면서 부위에 따라 적당한 부하를 집중시켜 적용할 수 있는 좋은 근력강화 운동법이며[17], Colado 등[18]은 전 범위에서 근육을 최대한 활성 화시키고 충격이 최소화되기 때문에 효과적인 운 동방법이라 하였다. 또한 이 운동법은 기구의 무게 로 인한 관절이나 근육에 부담을 주지 않으면서도 근력 강화는 물론, 관절가동범위의 증가, 유연성 향상 등의 효과를 주는 것으로 알려져 있으며, 개 인적인 재활 프로그램에 유용하게 적용 할 수 있 다고 하였다[19].

노인들을 대상으로 한 탄성밴드운동에서, 김도 진 등[8]은 체력 향상에 긍정적인 영향을 주었다고 하였고, Rogers, ME 등[20]은, 근기능이 향상되었
다고 하였으며, 여성노인에게 적용하였던 조사에서 윤수현[21]은 운동집단이 건강체력 수준과 골밀도 수준이 유지 또는 다소 증가하였으나 비운동집단 은 감소하였다고 하였다.

편마비 환자에게 적용한 경우에, 안선향[12]은 보행 및 신체적 기능장애에 효과가 있었다고 하였 고, 서충진 등[9]은, 중년 여성의 체지방 감소와 체 력에 도움이 된다고 하였으며, 또한 소휘영 등[22] 은, 비만 중년여성에게 적용한 결과 심폐기능 및 체력에 효과가 있다고 하였다.

이승병 등[10]은 어깨관절의 기능이 향상되었다 고 보고하였고, 김남정 등[11]은 상, 하지근력의 활 성도가 향상되었다고 보고하였으며, Matthew 등 [23]은 골관절염 환자에게 적용한 결과, 손 부위의 기능이 호전되었다고 보고하였다. 이는 상지근력 측정에서 '악력'이 향상된 것으로 나타났던 본 연 구의 결과와 일치하였다.

$\mathrm{ADL}$ 에 미치는 영향을 조사했던 김혜란[24]의 보고와 같이, 본 조사에서도 전체 대상자들의 $\mathrm{ADL}$ 기능 변화에서 대부분 도움이 되었다는 긍정 적인 반응을 보였다. 특히 '몸단장하기'와 '목욕하 기'에서 도움이 되었다는 답변이 많았으며, '화장실 사용하기'에서는 도움이 되지 않았다는 답변이 절 반을 차지해 유일하게 도움 정도가 높지 않은 수 치를 보였다. 이는 화장실 사용 시에 좌변기에 앉 고, 일어서는 등의 동작들이 주로 하지와의 관련성 이 많기 때문으로 추정된다.

남녀를 비교하여 분석한 결과를 보면, 남성의 경우 '목욕하기'에서 가장 도움이 많았던 것으로 나타났으며, 여성의 경우 '몸단장하기'가 가장 도움 이 많았던 것으로 나타났다.

\section{$\mathrm{V}$. 결론}

수명연장으로 인한 노인인구의 증가는 노인들에 대한 건강관리에 관심을 가져야 할 필요성이 제기 
되고 있으며, 가령(加齢)에 따른 노인의 신체적 허 약 또는 부분적 장애의 발생에 대한 지속적인 건 강관리가 요구된다. 규칙적인 운동은 노인건강관리 에 중요한 수단이며, 이러한 운동은 노인 개인이 용이하게 활용할 수 있고 지속적으로 시행할 수 있어야 그 효과가 극대화 될 수 있다.

최근에는 노인에게도 적절한 저항운동이 권장되 고 있는데[25], 밴드운동은 이러한 조건에 부합하 는 운동방법으로, 본 연구에서 밴드 저항운동 후의 상지근력을 운동 전과 비교 분석한 결과, '악력' '팔 구부리고 펴기' '에르고메터 측정' '엎드려 상 체 들기(남자)' '짐볼 던지기(여자)'항목 모두에서 유의하게 증가한 것으로 나타났다.

또한 밴드 저항운동 후의 $\mathrm{ADL}$ 기능변화 조사 에서는, '식사하기'(66.7\%) '몸단장하기' $(70 \%)$ '목욕 하기' $(70 \%)$ '옷 벗고 입기' $(60 \%)$ 항목에서 도움이 되었다고 응답하였으며, '화장실 사용하기' 항목에 서는 $50 \%$ 가 도움이 되었다고 하였다.

따라서 향후 활동이 가능한 노인 뿐 아니라 부 분적인 신체장애가 있는 노인에게도 적용할 수 있 는 밴드운동의 다양한 프로그램의 개발이 모색되 어져야 할 것이다.

\section{참고문헌}

1. 김석희, 류현승, 홍춘기(2011), 12 주간의 필라테스 매트운동과 탄력밴드운동이 여성노인의 혈중지질 과 신체수행능력에 미치는 영향, 운동학 학술지, Vol.13(1);103-112.

2. M.C. Morey(2002), Exercise Adherence and 10-Year Mortality in Chronically 111 Older Adults, J Am Geriatric Soc, Vol.50;1920-1933.

3. 문옥륜(2009), 한국 노인의료의 나아가야 할 방향. 대한 노인요양병원협회 2009년 추계학술집, pp.5-26.

4. 선우덕, 송현종, 이윤환, 김동진(2004), 허약 노인 대상의 보건의료서비스 개발 및 효율적 운영체계
구축 방안, 한국보건사회연구원, pp.46-49.

5. 강철구(2006), 재활운동 실천 후 양로시설 여성노 인의 일상생활활동, 수단적 일상생활활동 및 체력 변화에 관한 연구, 경기대학교 대학원 석사 학위 논문, pp.38-39.

6. 김수민(2010), 자가 재활운동이 장애노인의 일상활 동수행능력에 미치는 영향, 대한물리치료과학회지, Vol.17(1);53-66.

7. R.M. Patterson, C.W. Stegink Jansen, H.A. Hgan, et al(2001), Material Properties of thera-band tubing, Physical Therapy, Vol.81(8);1437-1445.

8. 김도진, 김종혁(2010), 노인을 위한 중량운동과 탄 성밴드 운동의 효과, 한국체육과학회지, $\mathrm{Vol}$. 19(2);1103-1115.

9. 서충진, 정희석, 장세봉 등(2008), 10 주간의 탄력밴 드 저항성 운동이 중년 여성의 체지방과 체력에 미치는 영향, 국제통합대체의학회지, Vol.4(1);39-47.

10. 이승병, 김선엽, 김병완 등(2009), 탄력밴드를 이용한 4 주간의 견관절 나선·직선운동이 견관절의 기능에 미치는 영향, 한국체육과학회지, Vol.18(2);1079-1092.

11. 김남정, 김현수, 이복환(2006), 뇌졸중환자의 상 하지 근활성도에 대한 탄력밴드운동의 효과, 운동 과학, Vol.15(4);329-335.

12. 안선향(2006), 탄성밴드를 이용한 근력훈련이 편마 비 환자의 보행 및 기능장애에 미치는 효과, 한국 체육대학교 사회체육대학원 석사학위논문, pp.47-48.

13. Kendall FP, McCreary EK, Provance PG(1993), Muscle Testing and Function. Baltimore, Williarms and Wilkins, pp.27-29.

14. 국민건강증진을 위한 운동능력평가 기준표(2000), 한국운동지도협회, pp.2-3.

15. Rikli, Jones(1999), Function fitness normative scores for community-residing adults age 60-94, Journal of Aging and Physical Activity, Vol.7;161-181.

16. B.M. Elizabeth, A. Kim, D. Botenhagen(2003), Exercise for Frail Elders, Human Kinetics Publishers Inc in U.S.A, pp.207-208. 
17. M. Tomas, T. Muller, M.W. Buses(2005), Quantification of tension in thera-band and can do tubing at different starting lengths, The Journal of sports Medicine \& Physical Fitness, Vol.45(2);188-198.

18. J.C. Colado, N.T. Triplett(2008), Effect of a short-term resistance program using elastic bands versus Weight machines for sedentary middle-age Women, Journal of Strength and Conditioning Research, Vol.22;1441-1448.

19. L. Lars Andersen, H. Christoffer, Oles. Mortensen, et al(2010), Muscle Activation and Perceived Loading During Rehabilitation Exercise: Comparison of Dumbbells and Elastic Resistance, Physical Therapy, Vol.90(4);538-549.

20. M.E. Rogers, H.S. Sherwoo, N.L. Rogers et al(2002), Effects of dumble and elastic band training on physical function in older inner-city African American women, Women \& Health, Vol.36(4);33-41.

21. 윤수현(2009), 6주간 탄력밴드 운동이 여성 노인 들의 건강관련 체력과 골밀도에 미치는 영향, 한 국체육대학교 사회체육대학원 석사학위논문, pp.19-20.

22. 소휘영, 전태원, 서동일 등(2008), 12 주간의 탄력 저항운동이 비만 중년여성의 신체조성, 심폐기능 및 체력에 미치는 영향, 대한비만학회지, Vol.17(3);132-148.

23. Matthew Wayne Rogers, MS, CSCS, Frances. Vaughn W(2009), Exercise and Hand Osteoarthritis Symptomatology: A Controlled Crossver Trial, Journal of Hand Therapy, Vol.22;10-18.

24. 김혜란(2008), 탄성밴드 및 짐볼운동이 노인들의 일상생활동작에 미치는 영향, 명지대학교 교육대 학원 석사학위논문, pp.40-41.

25. 김수민(2011), 신체장애 여성노인들의 침상재활운 동 후 일상생활수행능력 변화 연구, 보건의료산업
학회지, Vol.5(4);127-136.

접수일자 2012년 3월 28일

심사일자 2012년 5월 1일

게재확정일자 2012년 5월 14일 